\title{
TALOUS-NOBEL KOULUTUKSEN JA ARKIELÄMÄN TUTKIJALLE
}

Tämänvuotinen Nobelin talouspalkinto myönnettiin Chicagon yliopiston taloustieteen professori Gary S. Beckerille.

Vuonna 1930 Pottsvillessä Pennsylvanian osavaltiossa USA:ssa syntynyt Becker on "laajentanut taloudellisen analyysin inhimillisen kehityksen ja inhimillisten suhteiden uusille alueille", Ruotsin taideakatemia totesi palkinnon myöntämisperusteissa. Becker soveltaa tutkimuksissaan nk. rationaalisen toiminnan mallia, so. oletusta, että niin yksityiset ihmiset kuin kotitaloudet ja yritykset pyrkivät toimimaan järkiperäisesti tavoitellessaan hyvinvointia.

Beckerin voidaan sanoa kuuluvan ainakin kahden taloustieteen erikoisalan perustajien joukkoon. Tutkijauransa alkupuolella 1960-luvulla hän oli Theodore W. Schultzin (joka sai Nobelin vuonna 1979) ja Jacob Mincerin ohella keskeisesti vaikuttamassa siihen, että koulutuksen taloustiede eriytyi omaksi erikoisalakseen. Nk.inhimillisen pääoman teoriassa nämä tutkijat korostivat, että taloudellisen kasvun keskeisenä tekijänä on inhimillinen tieto ja ammattitaito.

Kun aikaisemmin oli työvoiman laadusta huolehtimista (terveydenhuolto, lastenhoito, koulutus jne.) pidetty taloudellisessa mielessä yksinomaan kulutuksena, inhimillisen pääoman teoriassa tietojen ja ammattitaidon hankkiminen nähdään investointina, joka tulevaisuudessa tuottaa hyötyä.

\section{Beckerin teosta pidetään koulutuksen taloustieteen klassikkona}

Beckerin teoksesta Human Capital, A Theo- retical and Empirical Analysis, with Special Reference to Education (1964, uusittu toinen painos 1975) muodostui uuden alan klassikko ja 1960-luvusta koulutuksen taloustieteen "kultaaika", jolloin Mark Blaugin (1985) arvion mukaan "no self-respecting Minister of Education would have dreamed of making educational decisions without an economist sitting at his right hand".

Seuraavalla vuosikymmenellä inhimillisen pääoman teorian "vulgaariversio" sai kuitenkin väistyä mahtiasemastaan koulutuksen taloustieteessä, kun uudet koulutuksen sosialisaatiofunktio-, seulonta (screening)hypoteesi- ja työmarkkinoiden segmentoitumisteoriat selittivät paremmin käytännön havaintoja koulutuksen mahdollisuuksista ja vaikutuksista.

Beckerin tutkimusten painopiste oli tällöin jo toisaalla.

\section{Arkielämän taloustiede}

Vuonna 1976 häneltä ilmentyi teos The Economic Approach to Human Behavior, joka laajensi taloustieteellistä tarkastelutapaa ja kysymyksenasetteluja moniin arkielämän ilmiöihin, alueille jotka aikaisemmin olivat olleet lähinnä sosiologien, psykologien ja sosiaaliantropologien kiinnostuksen kohteina. Tämä "the new economics of the family", uusi perheen taloustiede, tarkastelee $\mathrm{mm}$. avioitumisen, lasten hankkimisen, kotitöiden tekemisen, nukkumisen, työssäkäynnin, avioerojen, hampaiden pesun, ravintoloissa käynnin, tupakoinnin jne. ekonomiikkaa sosiaalisen elämän erilaisilla "markkinoilla". 
Beckerin muutamaa vuotta myöhemmin ilmestynyt teos $A$ Treatise on the Family (1981) lienee jo klassikko tällä tutkimusalueella.

Beckeria pidetään mielipiteiltään konservatiivisena, mutta aina mielenkiintoisena ja ajatuksia herättävänä tutkijana. Koomisiakaan sävyjä ei aivan kokonaan voida välttää, kun ihmiselämän profaanin puolen tutkiminen itsestäänselvyyksiltä kuulostavien tulosten saamiseksi käyttää raskasta ekonometristä analyysiapparaattia. Kun Becker esimerkiksi löytää tieteellisen selityksen sille, että "vähemmän viehättävät ja vähemmän älykkäät henkilöt avioituvat epätodennäköisemmin kuin viehättävämmät ja älykkäämmät henkilöt”, pitää Blaug (1980) tätä esimerkkinä, jota parempaa tuskin taloustieteelli- sestä kirjallisuudesta löytää, jossa pähkinä särjetään moukarilla".

Beckerin uuttaluovat kysymykset ja varsinaiset tieteelliset näytöt ovat kuitenkin niin vakuuttavia, että hänen tuotantonsa arvioitiin Nobelin palkinnon arvoiseksi. Ja työ jatkuu: pari vuotta sitten ilmestyi jälleen uusi teos, Human Capital, Fertility and Economic Growth.

\section{VIITTEET}

Blaug, M. 1980 The methodology of economics or how economists explain. Cambridge University Press: New York.

Blaug, M. 1985 Where Are We Now in the Economics of Education? Economics of Education Review, 4, 1, 17-28.

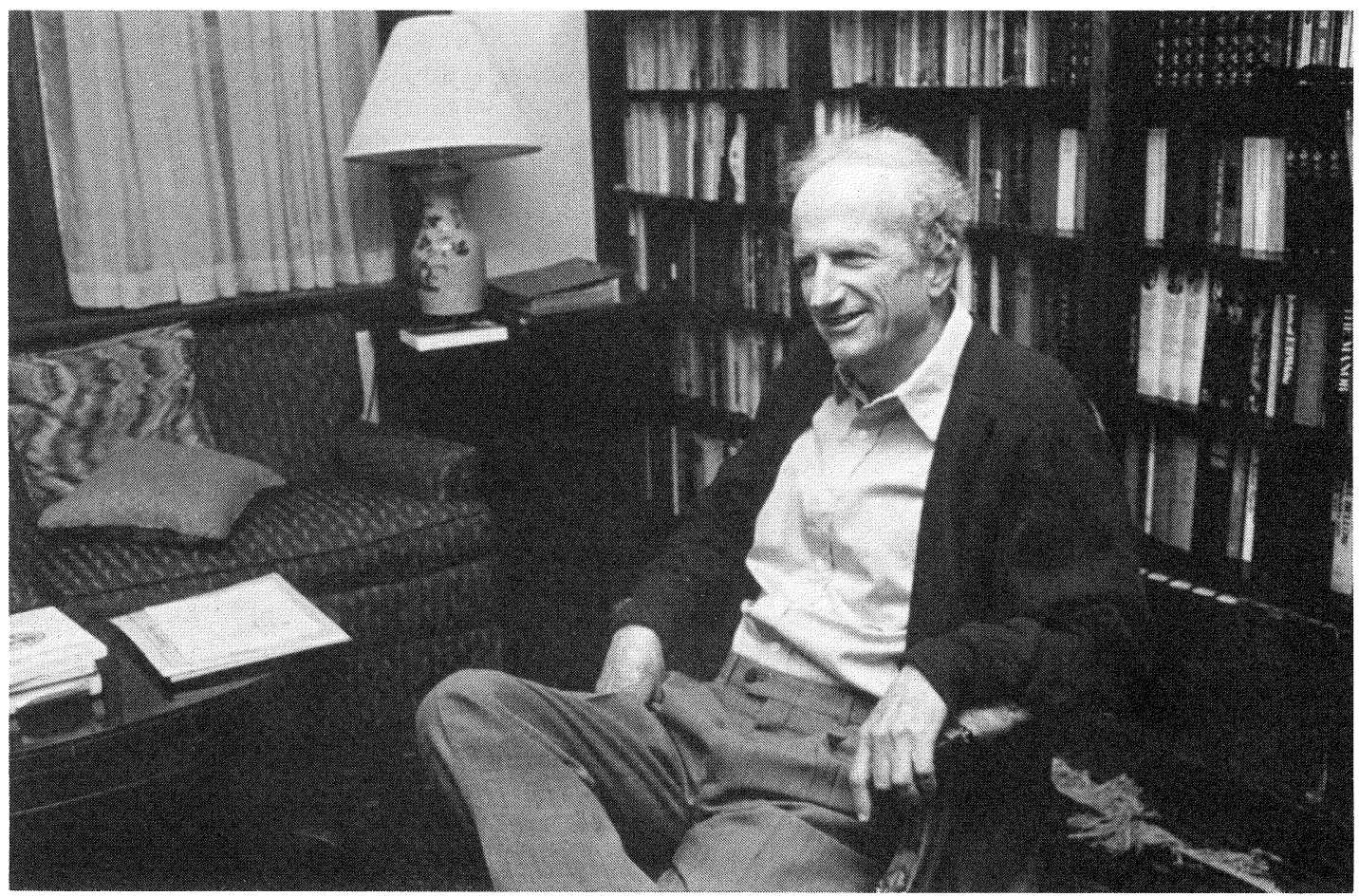

Gary S. Becker

\section{Rainer Aaltonen}

